\title{
SKRINING FITOKIMIA EKSTRAK JAMUR KANCING (Agaricus bisporus)
}

\author{
Asriani Suhaenah, Siska Nuryanti ${ }^{1}$ \\ Fakultas Farmasi, Universitas Muslim Indonesia \\ 1siska.nuryanti@umi.ac.id
}

\begin{abstract}
The phytochemical screenings and analysis of chemical compounds in $n$-hexan extract, ethyl acetat extract and ethanol extract, of Agaricus bisporus with Thin Layer Chromatography (TLC) has been carried out. Extraction process was performed with terraced maceration, identification of bioactive compound with thin layer chromatography. The result of Thin Layer Chromatography test showed that $n$-hexane extract contains flavonoid, coumarin, therpenoid and steroid. Ethyl acetate extract contains flavonoid, coumarine, therpenoid. Ethanol extract contains flavonoid, alkaloid, polyphenol, coumarin, terpenoid
\end{abstract}

Keywords: phytochemistry, TLC, Agaricus bisporus

\section{PENDAHULUAN}

Indonesia adalah negara agraris yang terkenal akan kekayaan rempah rempah dan berbagai jenis tanaman, dari dulu hingga sekarang tanaman herbal ataupun tanaman obat dapat menyembuhkan berbagai macam penyakit.

Salah satu tanaman yang berfungsi sebagai obat adalah jamur. Istilah jamur berasal dari bahasa Yunani, yaitu fungus (mushroom) yang berarti tumbuh dengan subur. Istilah ini selanjutnya ditujukan kepada jamur yang memiliki tubuh buah serta tumbuh atau muncul di atas tanah atau pepohonan. Organisme yang disebut jamur bersifat heterotrof, dinding sel spora mengandung kitin, tidak berplastid, tidak berfotosintesis, tidak bersifat fagotrof, umumnya memiliki hifa yang berdinding yang dapat berinti banyak (multinukleat), atau berinti tunggal (mononukleat), dan memperoleh nutrien dengan cara absorpsi (Gandjar et al., 2006). Penggunaan jamur sebagai obat merupakan tradisi yang sudah lama. Jamur kancing putih (Agaricus bisporus) adalah salah satu jamur yang paling popular yang diambil dari alam dan dari budidaya komersial. Agaricus bisporus kaya akan protein, asam amino bebas, polifenol, polisakarida ergothionin, vitamin. Jamur ini juga mengandung asam linoleat yang tingi dan enzim aromatase yang berperan mengkatalisis hormone seks pada manusia. Agaricus bisporus memiliki banyak fungsi seperti antioksidan, anti bakteri, anti inflamasi, anti tumor, dan sistem pertahanan tubuh (Falguera et al., 2011). Fenol adalah komponen antioksidan utama yang ditemukan pada ekstrak Agaricus bisporus (Dhamodharan \& Mirunalini, 2010). Menurut Jeong et al (2010) seluruh bagian dari jamur kancing (Agaricus bisporus) kaya akan serat, polisakarida, antioksidan, vitamin dan polifenol, dengan adanya kandungan tersebut, dapat memberikan efek terhadap sel dari sistem imun, sel tumor (Adams et al., 2008). Agaricus bisporus adalah sumber elemen yang bagus seperti natrium, potassium, dan fosfor, dikonjugasikan dengan asam linoleic dan antioksidan (Shiuan et al, 2005). Ini dapat menghambat aromatase, sehingga dapat menurunkan kadar estrogen pada tubuh manusia, dimana dapat mengurangi resiko kanker payudara. Pada tahun 2009, penelitian melalui 2000 wanita menunjukkan penurunan dalam jumlah besar orang yang mengkomsumsi jamur yang segar setiap hari, dimana $64 \%$ cenderung terkena kanker payudara. Ketika dikombinasikan antara jamur dengan konsumsi teh hijau yang teratur dapat mengurangi resiko kanker payudara sampai $90 \%$. Hal tersebut kemungkinan disebabkan oleh adanya peningkatan sistem pertahanan tubuh (Dhamodharan \& Mirunalini, 2010).

Melihat banyaknya khasiat tanaman dari jamur kancing tersebut diperkirakan tanaman tersebut mengandung bermacam-macam senyawa kimia yang berguna bagi kesehatan. Oleh karena itu pada penelitian ini dilakukan analisis komponen kimia jamur kancing dalam ekstrak n-heksan, ekstrak etil asetat dan ekstrak etanol.

\section{METODE PENELITIAN \\ A. Alat dan Bahan}

Alat-alat yang digunakan pisau stainless, timbangan kasar, timbangan analitik (Denvert instrument), bejana maserasi, corong, cawan porselin, vial, sendok besi, labu takar, beker gelas, erlenmeyer, mortir dan stamper, tabung reaksi, spektrofotometer UV-Vis (Shimadzu), Sonifikator, lampu UV, pipet kapiler (Nesco), lempeng KLT F 254. 
Bahan-bahan yang digunakan jamur kancing (Agaricus bisporus), aqudest, etanol, etil asetat, nheksan, kertas saring, aluminium foil, kertas timbang, methanol p.a, toluene, aseton, asam formiat, $\mathrm{AlCl}_{3}$, sitoborat, dragendorf, $\mathrm{KOH}$, Liberman-Burchard.

\section{B. Pengambilan dan Pengolahan Sampel}

Jamur kancing (Agaricus bisporus) yang akan digunakan dikumpulkan dan selanjutnya dibersihkan dari pengotor lalu dicuci dengan air mengalir hingga bersih. Jamur tersebut diiris tipistipis, kemudian dikeringkan di udara terbuka dan terlindung dari sinar matahari langsung, hingga didapatkan simplisia kering.

\section{Metode Ekstraksi}

Ekstraksi sampel dilakukan secara bertingkat dengan ultrasonifikasi, simplisia ditimbang sebanyak 25 gram, lalu ditambahkan pelarut yang non polar yaitu n-heksan, sebanyak $125 \mathrm{~mL}$, kemudian ditempatkan di dalam ultrasonic bath selama 30 menit dengan frekuensi gelombang $38 \mathrm{kHz}$. kemudian disaring, kemudian ditambahkan lagi dengan $125 \mathrm{ml}$ n-heksan, dan disonifikasi selama 30 menit, kemudian disaring, hasil saringan kemudian diuapkan untuk mendapatkan ekstrak n-heksan. Kemudian residu dikeringkan dan setelah kering, dimaserasi lagi dengan pelarut semi polar yaitu etil asetat sebanyak $125 \mathrm{ml}$ dengan sonikator, dan dilakukan sebanyak 2 kali, kemudian hasil saringan diuapkan untuk mendapatkan ekstrak etil asetat. Selanjutnya residu dikeringkan dan setelah kering ditambahkan dengan $125 \mathrm{ml}$ peratut polar yaitu etanol, dan dimaserasi kembali dengan sonifikator sebanyak 2 kali, kemudian hasil saringan diuapkan untuk mendapatkan ekstrak etanol.

\section{Uji Kandungan senyawa bioaktif dengan Kromatografi lapis tipis}

Ekstrak kental sampel dan asam galat secukupnya masing-masing dilarutkan dengan metanol, selanjutnya ditotolkan pada lempeng KLT. Kemudian lempeng dielusi dengan campuran pelarut butanol ; asam galat ; air (BAW) dengan perbandingan $(6: 1: 3)$. Spot noda yang diperoleh pada lempeng setelah kering, lalu disemprot dengan $\mathrm{FeCl}_{3}$. Jika spot noda hasil penyemprotan tersebut berwarna biru kehitaman maka sampel tersebut positif mengandung senyawa fenolik. Uji kandungan senyawa bioaktif atau metabolit sekunder dari tanaman jamur kancing (Agaricus bisporus) untuk masing-masing ekstrak dilakukan sebagai berikut:

\section{Senyawa flavonoid}

Ekstrak hexan, etil asetat dan etanol masing-masing dilarutkan kemudian ditotolkan pada lempeng silica gel $\mathrm{G}_{60} \mathrm{~F}_{254}$ dan dielusi dengan menngunakan Toluen : Aseton :asam Formiat (6:6:1). Lempeng dikeringkan dan disemprot dengan pereaksi $\mathrm{AlCl}_{3}$ dan sitroborat. Hasil positif adanya senyawa flavonoid ditandai dengan spot/bercak berfluoresensi kuning kehijauan pada UV 366

\section{Senyawa Alkaloid}

Ekstrak hexan, etil asetat dan etanol masing-masing dilarutkan kemudian ditotolkan pada lempeng silica gel $\mathrm{G}_{60} \mathrm{~F}_{254}$ dan dielusi dengan menngunakan Toluen : Aseton :asam Formiat (6:6:1). Lempeng dikeringkan dan disemprot pereaksi dragendorf. Hasil positif adanya alkaloid ditandai dengan adanya bercak/spot berwarna orange.

\section{Senyawa polifenol}

Ekstrak hexan, etil asetat dan etanol masing-masing dilarutkan kemudian ditotolkan pada lempeng silica gel G60 $\mathrm{F}_{254}$ dan dielusi dengan menngunakan Toluen : Aseton :asam Formiat (6:6:1). Lempeng dikeringkan dan disemprot dengan pereaksi $\mathrm{FeCl}_{3}$. Hasil positif Hasil positif ditandai dengan adanya spot/bercak berwarna gelap (hitam, ungu, biru tua atau coklat tua).

\section{Senyawa antrakuinon dan kumarin}

Ekstrak hexan, etil asetat dan etanol masing-masing dilarutkan kemudian ditotolkan pada lempeng silica gel $\mathrm{G} 60 \mathrm{~F}_{254}$ dan dielusi dengan menngunakan Toluen : Aseton :asam Formiat (6:6:1). Lempeng dikeringkan dan disemprot dengan $\mathrm{KOH}$ metanolik dan Hasil positif adanya senyawa kumarin ditandai dengan spot berfluoresensi biru terang di bawah lampu UV 366 dan spot berwarna merah untuk senyawa antakuinon

\section{Senyawa terfenoid dan steroid}

Ekstrak hexan, etil asetat dan etanol masingmasing dilarutkan kemudian ditotolkan pada lempeng silica gel $\mathrm{G} 60 \mathrm{~F}_{254}$ dan dielusi dengan menngunakan Toluen : Aseton :asam Formiat (6:6:1). Lempeng dikeringkan dan disemprot dengan pereaksi Libermann-Burchard. Hasil positif ditandai dengan adanya spot/bercak berwarna hijau-biru untuk senyawa steroid dan warna merah untuk senyawa triterpenoid. 
III. HASIL DAN PEMBAHASAN

A. Hasil Penelitian

Tabel 1. Kandungan senyawa bioaktif ekstrak Agaricus bisporus berdasarkan kromatografi lapis tipis

\begin{tabular}{cccc}
\hline $\begin{array}{c}\text { Kandungan } \\
\text { bioaktif }\end{array}$ & $\begin{array}{c}\text { Ekstrak } \\
\text { n-hexan }\end{array}$ & $\begin{array}{c}\text { Ekstrak } \\
\text { etil } \\
\text { asetat }\end{array}$ & $\begin{array}{c}\text { Ekstrak } \\
\text { etanol }\end{array}$ \\
\hline Flavonoid & + & + & + \\
Alkaloid & - & - & + \\
Polyfenol & - & - & + \\
Antrakuinon & - & - & - \\
Kumarin & + & + & + \\
Terpenoid & + & + & + \\
Steroid & + & - & - \\
\hline Keterangan : + & : Positif & & \\
- & : negatif & &
\end{tabular}

Hasil Uji Senyawa Bioaktif Dengan menggunakan Kromatografi Lapis Tipis

\section{Senyawa Flavonoid}
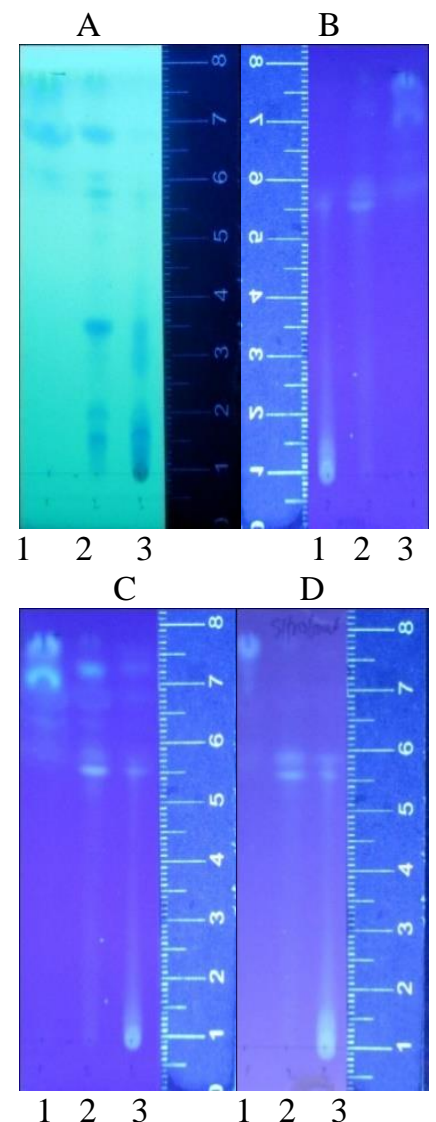

Gambar 1. Hasil uji KLT (Kromatografi Lapis

Tipis) untuk uji senyawa Flavonoid
Keterangan gambar

Fase diam : Silika gel G60 $\mathrm{F}_{254}$

Fase gerak : Toluen : Aseton :asam Formiat $(6: 6: 1)$

1. Ekstrak n-heksan

2. Ekstrak Etil asetat

3. Ekstrak etanol

A. UV 254

B. UV 366

C. $\mathrm{AlCl}_{3}$

D. Sitroborat

Hasil positif adanya senyawa flavonoid ditandai dengan spot/bercak berfluoresensi kuning kehijauan pada UV 366 stelah disemprot dengan pereaksi $\mathrm{AlCl}_{3}$ dan sitroborat

Hasil: semua ekstrak mengandung senyawa flavonoid

\section{Senyawa Alkaloid}

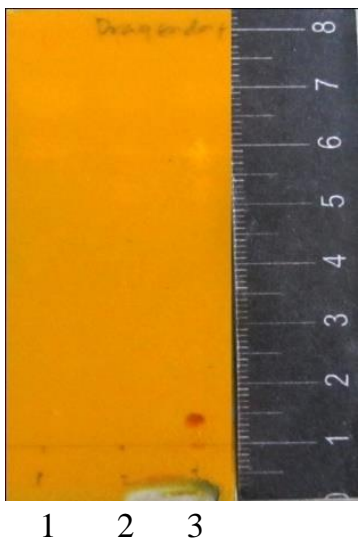

Gambar 2. Hasil uji KLT (Kromatografi Lapis Tipis) untuk uji senyawa alkaloid

Keterangan Gambar

Fase diam : Silika gel $\mathrm{G}_{60} \mathrm{~F}_{254}$

Fase gerak : Toluen : Aseton :asam Formiat $(6: 6: 1)$

1. Ekstrak n-heksan

2. Ekstrak Etil asetat

3. Ekstrak etanol

Hasil positif ditandai dengan adanya bercak/spot berwarna orange setelah disemprot dengan pereaksi dragendorf.

Hasil: ekstrak etanol mengandung senyawa alkaloid, ekstrak n-heksan dan etil asetat tidak mengandung alkaloid 


\section{Senyawa polifenol}

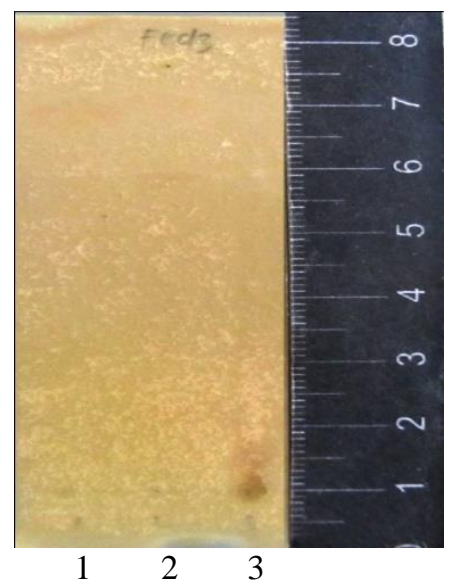

Gambar 3. Hasil uji KLT (Kromatografi Lapis Tipis) untuk uji senyawa polifenol

Keterangan Gambar

Fase diam : Silika gel G60 $\mathrm{F}_{254}$

Fase gerak : Toluen : Aseton :asam Formiat $(6: 6: 1)$

1. Ekstrak n-heksan

2. Ekstrak Etil asetat

3. Ekstrak etanol

Hasil positif ditandai dengan adanya spot/bercak berwarna gelap (hitam, ungu, biru tua atau coklat tua) setelah disemprot dengan pereaksi $\mathrm{FeCl}_{3}$.

Hasil: Ekstrak etanol positif mengandung polifenol

\section{Senyawa Antrakuinon dan Kumarin}

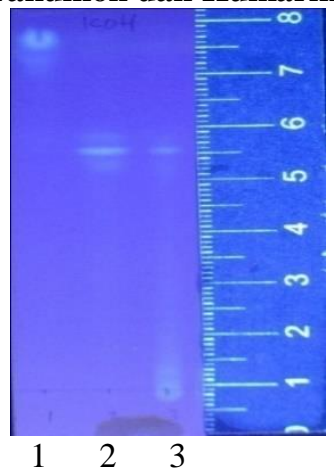

Gambar 4. Hasil uji KLT (Kromatografi Lapis

Tipis) untuk uji senyawa antrakuinon dan kumarin

Keterangan Gambar

Fase diam : Silika gel G60 $\mathrm{F}_{254}$

Fase gerak : Toluen : Aseton :asam Formiat

1. Ekstrak n-heksan

$$
(6: 6: 1)
$$

2. Ekstrak Etil asetat

3. Ekstrak etanol
Hasil positif adanya senyawa kumarin ditandai dengan spot berfluoresensi biru terang di bawah lampu UV 366 dan spot berwarna merah untuk senyawa antakuinon stelah disemprot dengan $\mathrm{KOH}$ metanolik.

Hasil: semua ekstrak positif memgandung kumarin, sedangkan negative mengandung antrakuinon

\section{Senyawa Terpenoid dan steroid}

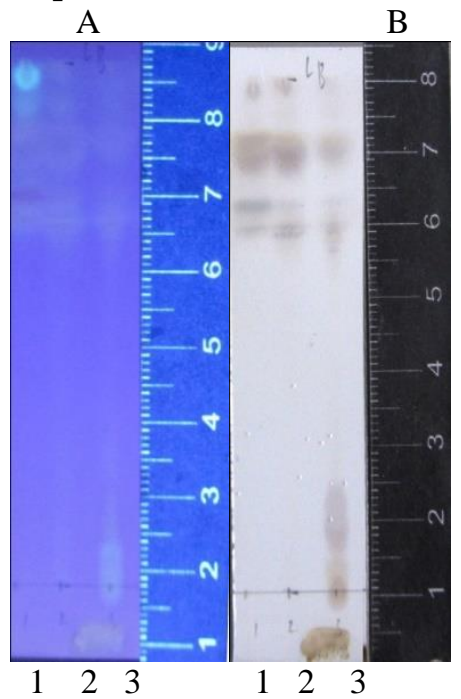

Gambar 5. Hasil uji KLT (Kromatografi Lapis Tipis) untuk uji senyawa terpenoid dan steroid

Keterangan Gambar

Fase diam : Silika gel $\mathrm{G} 60 \mathrm{~F}_{254}$

Fase gerak : Toluen : Aseton :asam Formiat $(6: 6: 1)$

1. Ekstrak n-heksan

2. Ekstrak Etil asetat

3. Ekstrak etanol

4. Libermann-Burchard (di bawah UV 366)

5. Libermann-Burchard (Visibel)

Hasil positif ditandai dengan adanya spot/bercak berwarna hijau-biru untuk senyawa steroid dan warna merah untuk senyawa triterpenoid setelah disemprot dengan pereaksi LibermannBurchard.

Hasil: Ekstrak n-heksan mengandung senyawa steroid, dan Semua ekstrak mengandung triterpenoid.

\section{B. Pembahasan}

Tanaman yang digunakan pada penelitian ini adalah jamur kancing (Agaricus bisporus). Ekstraksi dilakukan dengan maserasi bertingkat, dengan metode ultrasonikasi. 
ekstraksi dengan menggunakan gelombang ultrasonik. Metode ini tidak membutuhkan waktu yang lama dibandingkan dengan metode maserasi ataupun soxhletasi. Prinsip ekstraksi ultrasonik adalah peningkatan transfer massa yang disebabkan oleh meningkatnya penetrasi pelarut ke dalam jaringan tumbuhan lewat efek kapiler. Gelembung kavitasi akan terbentuk pada dinding sel tanaman akibat adanya gelombang ultrasonik. Efek dari pecahnya gelembung kavitasi ini dapat mengakibatkan peningkatan pori-pori dinding sel. Pecahnya gelembung kavitasi disebabkan oleh tipisnya bagian kelenjar dalam sel tumbuhan yang mudah dirusak dengan sonikasi. Hal tersebut memudahkan pelepasan komponen esensial ke dalam pelarut, dengan kata lain, gelombang ultrasonic dapat memfasilitasi terjadinya pembengkakan sel dan pelarutan komponen dalam tanaman yang disebabkan pembesaran pori-pori dinding sel. Pembengkakan pori yang lebih besar akan meningkatkan transfer massa sehingga dapat meningkatkan efisiensi dan mengurangi waktu ekstraksi (Melecchi et al., 2006). Kelebihan lain dari ekstraksi ultrasonic adalah keterulangan ekstraksi baik, waktu ekstraksi yang jauh lebih singkat, lebih efisien, dan dapat digunakan untuk ukuran sampel yang beragam. Ekstraksi ultrasonic sangat baik digunakan untuk ekstraksi komponen organik polar (Said, 2009).

Simplisia diekstraksi dengan menggunakan pelarut dengan kepolaran bertingkat yaitu pelarut nheksan, etil asetat, dan etanol. Ekstraksi dengan cara bertingkat dilakukan supaya senyawa bioaktif yang bersifat non-polar diharapkan tersari dalam pelarut nheksan, semi polar tersari dalam etil asetat dan yang bersifat polar dapat tersari dalam etanol. Hasil masing-masing ekstrak yang diperoleh kemudian diidentifikasi secara kualitatif dengan menggunakana kromatografi lapis tipis (KLT).

Kromatograpi lapis tipis adalah metode pemisahan senyawa bioaktif secara kimia fisika berdasarkan perbedaan kecepatan migrasi atau ratio distribusi dari komponen campuran fase diam dan fase gerak (Kusumaningtyas et al., 2008). Identifikasi senyawa bioaktif dengan kromatografi lapis tipis ditandai dengan menggunakan pereaksi semprot.

Hasil Penelitian (tabel 1) menunjukkan bahwa uji flavonoid pada berbagai ekstrak diperoleh bahwa pada semua ekstrak positif mengandung flavonoid, namun pada ekstrak n-heksan intensitas kandungan flavonoid bersifat lemah, hal ini terjadi karena senyawa golongan flavonoid bersifat polar. Kepolaran senyawa tersebut dikarenakan flavonoid merupakan senyawa polihidroksi (memiliki lebih dari satu gugus hidroksil) (Satrohamidjojo, 1996).
Pemeriksaan alkaloid pada ekstrak n-heksan, etil asetat dan etanol menunjukkan bahwa ekstrak etanol positif mengandung alkaloid. Adanya alkaloid dalam ekstrak tersebut disebabkan karena alkaloid bersifat polar dan non polar (harborne 1987). Pada ekstrak etil asetat dan n-heksan tidak terdapat senyawa alkaloid, hal ini mungkin disebabkan alkaloid lebih banyak dalam bentuk garamnya sehingga umumnya larut dalam senyawa polar seperti air atau etanol (Bruneton, 1993).

Pemeriksaan senyawa polifenol/tannin menunjukkan hasil positif pada ekstrak etanol. Hal ini sesuai dengan penyataan Sriwahyuni (2010), pada senyawa polifenol/tannin terdapat banyak gugus $\mathrm{OH}$ sehingga menyebabkan sifatnya polar, sehingga larut dalam senyawa polar seperti etanol.

Pada pemeriksaan antrakuinon, semua sampel negatif mengandung antrakuinon, Hal ini tidak sesuai dengan teori yang menyatakan bahwa senyawa antrakuinon dapat larut dalam lemak dan etanol encer (Harborne 1987), sedangkan pada pemeriksaan kumarin, semua sampel positif mengandung kumarin. Hasil tersebut seuai dengan teori yang menyatakan bahwa senyawa kumarin biasanya terdapat dalam senyawa polar maupun yang bersifat non polar. (harborne, 1987)

Pemeriksaan terpenoid dan steroid yang dilakukan pada masing-masing ekstrak menunjukkan bahwa senyawa terpenoid terdapat pada semua ekstrak, dan senyawa steroid hanya terdapat pada ekstrak n-heksan, sedangkan pada etil asetat dan etanol negatif mengandung steroid. Hal ini sesuai dengan teori yang menyatakan bahwa senyawa steroid umumnya larut dalam senyawa non polar (Harborne, 1987).

\section{KESIMPULAN}

Kandungan senyawa bioaktif dari ekstrak nheksan adalah flavonoid, kumarin, terpenoid dan steroid, ekstrak etil asetat mengandung flavonoid, kumarin, triterpenoid, sedangkan ekstrak etanol mengandung flavonoid, alkaloid, polifenol, kumarin, terpenoid.

\section{DAFTAR PUSTAKA}

Adams L.S. et al. (2008). White button mushroom (Agaricus bisporus) exhibits antiproliferative and proapoptotic properties and inhibits prostate tumor growth in athmic mice. Nutr cancer

Bruneton J. (1993). Pharmacognosy, Phytochemistry, Medicinal Plants. Lavoisier Publishing, Paris

Dhamodharan G, \& Mirunalini S. (2010). A Novel Medicinal Characterization of Agaricus bisporus (white button mushroom). Pharmacology online 2:456-463 
Falquera V., Miarnau O., Pangan J\& Ibarz A. (2011).Inhibitory effect of melanins from Agaricus bisporus polyphenol oxidase and two different substrats on carboxypeptidase $A$ and $B$ activity

Gandjar I.G. \& Rohman. (2007). Kimia Analisis Farmasi. Yogyakarta: Pustaka Pelajar

Harborne I.B. (1987). Metode Fitokimia. Penerbit ITB Bandung. (Dictionanry Of Natural Product)

Jeong SC., Jeong Yt., Yang BK., Islam R., Koyyalamudia SR., Panga G, Choa K.Y., \& Song C.H. (2010). White button Mushroom (Agaricus bisporus) lower blood glucose and cholesterol level in diabetic and hypercholesterolemic rats. Nutr Res 30: 4956

Kusumaningtyas E., Astuti E.,\& Darmono. (2008). Sensitivitas Metode Bioautografi Kontak dan Agar Overlay Dalam Penentuan Senyawa Antikapang. Jurnal Ilmu Kefarmasian, September. Vo.6 No.2 Hal 75-79

Melechi et al. (2006). Optimization of The Sonication Extraction Method of Hibiscus tiliaceus L.Fkowers. Ultrasonics Sonochemistry 13:242-250

Said KABM. (2009). Ultrasonic Extraction of Antioxidant Compound in Guava (Tesis) Pahang. Faculty of Chemical \& Natural Resources Engineering, University Malaysia Pahang.

Sastrohamidjojo. (1996). Sintesis Bahan Alam. Cetakan Pertama. Yogyakarta, Gadjah Mada University Press

Shiuang Chen., Sheryl Phung., Gene Hur., Sharon Kwok., Jingjing Ye., \& Sei-Ryang Oh. (2005). Breast cancer prevention with phytochemical in mushrooms. Proc Amer Assoc Cancer Res, Volume 46,5186

Sriwahyuni I. (2010). Uji Fitokimia Ekstrak Tanaman Anting-anting (Acalypha indica Linn) dengan variasi pelarut dan Uji Toksisitas menggunakan Brine Shrimp (Artemia salina Laeach). Skripsi: Universitas Negri Islam Maulana Malik Ibrahim, Malang 